\title{
Średniowieczna architektura Gruzji
}

\author{
ks. Levan Varsimaszvili \\ Chrześcijańska Akademia Teologiczna w Warszawie \\ Polska \\ levan.varsimashvili@o2.pl
}

rev. L. Varsimaszvili, Medieval architecture of Georgia, Elpis, 21 2019: 59-69.

\begin{abstract}
For many centuries Christian sacral life was a main trigger in the general development of Georgian culture. Various Christian temples with exclusive, typical for this part of the world features and details, constituted an important element of the social and political life of the country. It also played an important role in spreading Christian faith in the region. This specific Georgian sacral architectural style was finally formed in V-VI centuries AD. The best sample of this style could be the Sioni Cathedral in Bolnisi that survived till now. The golden age of the sacral Christian architecture in Georgia falls on the X-XIII centuries, when a numerous monumental and expressive Christian temples have been created. The development of this trend started to loose it's tempo in the 14th century, when Georgia suffered a constant unrest caused by the aggressive and destructive activity of the neighboring countries.

Streszczenie: Od wieków życie sakralne odgrywało kluczową rolę w rozwoju kultury Gruzji. Rozmaite budowle sakralne, wyróżniające się indywidualnością oraz cechami takimi jak konstrukcje świątyń trójkościelnych, które nie występują w żadnym innym regionie świata, stanowiły istotny element życia społecznego i politycznego, szerzenia wiary, jak również stanowiły o rozwoju wyodrębnionego gruzińskiego nurtu architektonicznego. Powstanie usystematyzowanej chrześcijańskiej sztuki sakralnej w Gruzji przypada w przybliżeniu na V-VI wieku n.e. czego przykładem jest istniejąca po dziś Katedra Sioni w Bolnisi. Złoty okres rozwoju budownictwa sakralnego na terenie Gruzji przypada na X-XIII wiek, kiedy to powstaje wiele znaczących, monumentalnych i ekspresywnych budowli sakralnych. Gruziński postęp osiągnięty w czasach późnego średniowiecza wyhamował jednak w XIV wieku poprzez ciągłe niepokoje spowodowane niszczącymi kraj oraz godzącymi w jego suwerenność zbrojnymi agresjami krajów sąsiednich.
\end{abstract}

Keywords: The Georgian Orthodox Church, Georgian architecture

Słowa kluczowe: Gruzińska cerkiew prawosławna architektura gruzińska

\section{Średniowieczna architektura Gruzji}

Wielki wpływ na rozwój historii architektury gruzińskiej miało jej położenie geograficzne. Gruzja usytuowana jest na pograniczu Europy i Azji, na skrzyżowaniu dróg Wschodu i Zachodu. Otoczona krajami azjatyckimi Gruzja na samym początku swej historii obrała drogę w stronę Europy i ani razu nie zmieniła kierunku, przyjmując chrześcijaństwo prawie jednocześnie z krajami regionu śródziemnomorskiego.

Architektura gruzińska wraz ze wszystkimi swoimi podstawowymi rodzajami kultury wyróżnia się rozmaitością. W wyniku wielu inwazji na tereny kraju w różnych okresach historycznych wiele zabytków architektonicznych zostało zniszczonych, ale zachowane do dnia dzisiejszego fragmenty owych konstrukcji świadczą o wysokim stopniu rozwoju architektury gruzińskiej.

Całokształt kultury gruzińskiej liczy sobie tysiąclecia, jednakże o powstaniu i rozwoju indywidualnych form architektonicznych można mówić w przybliżeniu od V-VI wieku n.e.

Architektura średniowieczna, podobnie jak sztuka gruzińska, w całości może być klasyfikowana zgodnie z najważniejszymi okresami następująco:

1. Wczesny okres rozwoju architektury średniowiecznej - od IV do połowy wieku VII. Ten okres częściowo zgadza się z tak zwaną wczesnochrześcijańską epoką na Bliskim i Środkowym Wschodzie oraz w Europie, przedstawia on rozkwit architektury gruzińskiej.

2. Okres przejściowy - od połowy wieku VII do połowy wieku $\mathrm{X}$. Jest to okres etapowego przejścia od zasad poprzedniego stylu, aż po rozwój nowych zasad i stworzenie oraz adaptację nowego stylu.

3. Architektura średniowiecza to złoty wiek sakralnej architektury gruzińskiej, poczynając od drugiej połowy X aż do przełomu wieków XIII i XIV.

4. Późniejszy okres rozwoju średniowiecznej architektury gruzińskiej - to okres XIV-XVIII wieków, kiedy podzielona na części Gruzja przeżywała zbrojne agresje państw sąsiadujących i walczyła o własną niepodległość, Europa Zachodnia zaś wkroczyła do epoki Odrodzenia, a kultura rosyjska przechodziła przez okres reform progresywnych.

W Pierwszych wiekach ekspansji wiary chrześcijańskiej w Gruzji podczas ceremonii wierni znajdowali się poza murami cerkwi, a dostęp do wnętrza budynku mieli wyłącznie kapłani. Powodem były małe rozmiary pierwszych świątyń, przypominających swoimi rozmiarami późniejsze kapliczki. Rozwiązanie to, gdzie wierni pozostawali na zewnątrz obiektów religijnych, tłumaczono trwogą przed Bogiem. Dowody na to znaleźć można m.in. $\mathrm{w}$ dawnym gruzińskim podaniu z $\mathrm{V}$ wieku, ,Mokcewai 
Kartlisai" (Nawrócenie Kartlii), gdzie anonimowy autor pisze: „Wielkim byt strach przed nowym Bogiem”. W późniejszym okresie cerkiew chrześcijańska w celu przybliżenia ludzi do Boga postawiała przed inżynierami całkiem nowe wyzwanie. Polegało ono na stworzeniu budynku szczególnego, zarówno pod względem estetycznym, jak i funkcjonalnym pozwalającym przebywać pod jego dachem dużej ilości wierzących oraz da możliwość przeprowadzenia obrządków religijnych przy liczniejszym gronie wyznawców. Bardziej przestronne cerkwie zaczęto budować pod koniec wieku V. Architekci gruzińscy poszukując przykładów i inspiracji coraz częściej spoglądali na tradycyjne miejscowe budowle, charakteryzujące się strukturą planowania pionowego, tego rodzaju typ budynku nazywano „,domem kolchidzkim”.

Chrześcijaństwo dotarło do Gruzji Wschodniej w IV wieku. Nie była to jeszcze religia ostatecznie sformowana. W sztuce, zarówno jak i w architekturze w tym okresie nie obserwujemy też form ostatecznych, skończonych, gdyż był to czas kształtowania myśli religijnej. Zatarg nowej religii z kultem narodowym powołał do życia potrzebę stworzenia nowej sztuki sakralnej. Proces ten jednak wymagał pewnego czasu. W Gruzji stworzona została swoista wersja bazylik charakterystyczna dla regionu, którą uczeni gruzińscy określili jako „,bazylikę trójkościelna/trzechcerkiewna”. Z zewnątrz nie różni się ona od zwyczajnej bazyliki trójnawowej, jednak wewnątrz nawy są odseparowane od siebie nie kolumnami, a ścianami. Sprowadzato się to do jednej konstrukcji architektonicznej, gdzie złaczone zostaty trzy niezależne kaplice. Jest to typ kościoła nieznany poza granicami Gruzji (Čubinašvili, 1936).

Trójkościelna bazylika Nekresska, która znajduje się w Kachetii, położona na zboczu góry $\mathrm{w}$ towarzystwie klasztoru odległa jest o 9 kilometrów od wsi Szildi. Świątynia ta różni się od trójkościelnej bazyliki starego stylu, gdzie trzy sąsiadujące przestrzenie łączą się ze sobą jedynie otworami na drzwi. W Nekresi, bazylice z VII wieku, został wprowadzony zupełnie nowy styl architektury. W przestrzeni wewnętrznej dominuje wysoka i objętościowa środkowa nawa. W roli bocznych naw występuje niski narteks łączony z nawą centralną trzema drzwiami. W przestrzeni wewnętrznej po obu stronach apsydy ołtarza środkowego kościoła znajdują się oddzielne komory - ołtarz i diakonnik. Wejścia do pastoforii kościoła znajdują się na północnej i południowej ścianie przy ołtarzu nawy głównej, a do przedsionka światło dociera wyłącznie przez drzwi. Bazylika Nekresska zbudowana jest z dość dużych ociosanych kamieni. Kąty i inne ważne architektoniczne elementy wykonane są z pumeksu, co jest typowe dla architektury Kakheti. Kaplica ołtarzowa kościoła centralnego ma kształt półkola charakterystycznego dla wczesnego średniowiecza. Środkowa nawa bazyliki trójkościelnej Nekresi była malowana w XV wieku, a obrazy w reprezentacyjnej części przedstawiają króla Kachetii

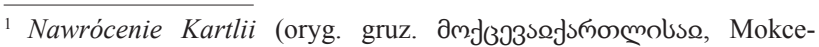
wajKartlisaj) - zabytek literatury starogruzińskiej, najstarsza znana kronika gruzińska.
}

Lewana (1520-1574), królową Tinatin i młodego następcę tronu. Tym samym w trójkościelnej bazylice Nekresi pojawił się zupełnie nowy, architektonicznie i kompozycyjnie uformowany, integralny typ budowli religijnej, którego elementami są niezależne pastoforia oraz inne rozwiązania architektoniczne umożliwiające integrację wszystkich trzech naw bocznych w jednym przedsionku. Istotne jest, iż każdy kościół zachował niezależną funkcjonalność, co było podstawowym warunkiem dla trójkościelnej bazyliki.

Szczególnie ważne z punktu widzenia gruzińskiej historii sztuki jest wczesnośredniowieczne zakorzenienie tego rodzaju architektury w Abchazji, gdzie z licznych przykładów można wymienić m.in. trójkościelną bazylikę w Starej Gagrze, czy też twierdzę Abaaneti w Misra (Severov, 1947). Krytycy sztuki zgodnie przyznają, iż styl bazyliki trójkościelnej powstał w Gruzji, na terenie której spotkać można się ze wszystkimi etapami architektonicznego rozwoju, wykazując i jest to zespół cech konstrukcyjnych charakterystycznych jedynie dla regionu, niewystępujący poza gruzińskimi granicami.

Charakterystyczna dla regionu i warta uwagi jest Katedra Sioni w Bolnisi, będąca najstarszą zachowaną chrześcijańską świątynią na terenie Gruzji, która jest trójnawową budowlą z V wieku, nakrytą dwuspadowym dachem. Jest to trójnawowa bazylika z pięcioma paroma równoległych filarów i absydą. Wejście do bazyliki w tego rodzaju obiektach znajduje się zwykle od strony zachodniej, jednakże w Bolniskim Sioni wejścia znajdują się od strony północnej i południowej. Choć rozmiary bazyliki są niewielkie, jej szerokie ściany na zewnątrz wyłożone są szmaragdowym tufem, co dodatkowo podkreśla dostojność i wzniosły charakter budowli. Efekt ten wzmacniają również proste i harmonijne proporcje bazyliki. Świątynię cechują ascetyczna powściągliwość w dekoracjach, w rzeźbie dominują motywy roślinne, a krzyż o formie charakterystycznej tylko dla tej bazyliki nazywany jest „,krzyżem Bolnisi”. To krzyż wpisany w okrąg, ramiona którego rozszerzają się oraz otoczone są małymi trójkątami. Na ścianach bazyliki zachowały się najstarsze inskrypcje w języku gruzińskim, dzięki którym ustalono datę powstania kościoła (lata 478-493).

Innym przykładem gruzińskiej architektury jest bazylika Anczischati pod wezwaniem Najświętszej Marii Panny, która pochodzi z VI wieku. Cerkiew znajduje się na początku ulicy Szawteli w starej dzielnicy Tbilisi Kala, położonej na prawym brzegu rzeki Mtkwari. Według „Nawrócenia Kartli”, za panowania spadkobiercy króla Wachtanga Gorgasali - Daczi Udżarmeli „zebrali się tbiliscy mieszczanie i wybudowali kościót pod wezwaniem Najświętszej Marii Panny”. Kościół został nazwany „Anczischati" w XVII wieku, kiedy Turcy próbowali umocnić swoje panowanie w Gruzji Południowej. Wtedy też z klasztoru w Ancziani została przeniesiona do Anczischati ikona Zbawiciela wykonana przez Bekę Opizari w XII wieku. Nazwa przetrwała do chwili obecnej, w związku z tym kościól, wzniesiony na cześć Bogorodzicy, nosi go do dzisiaj.

Anczischati jest typową trójnawową bazyliką. Do jej wnętrza prowadzą trzy wejścia - dwa w ścianach bocznych 
i jedno w ścianie zachodniej. Podobnie jak w bazylice Urbnisi, nawa główna jest dość wysoka i nakryta jest dachem dwuspadowym. Kościół zbudowany z ociosanego kamienia stanowi zamknięty czworobok. Oddzielne pomieszczenia na ołtarz i diakonnik z każdej strony apsydy wskazują, iż trójdzielny rzut przyziemia świątyni był dobrze znany we wczesnochrześcijańskiej architekturze gruzińskiej. Początkowo całe wnętrze budynku dzieliły trzy pary kolumn o przekroju w kształcie krzyża. W XVII wieku dodano dwie nowe pary okrągłych kolumn z cegły, które znacząco zmieniły wystrój wnętrza. Wewnątrz oraz z przodu apsydy zachowały się fragmenty malarstwa ściennego z 1683 r. oraz freski wykonane w $1814 \mathrm{r}$. Centralne wejście do bazyliki znajduje się od strony zachodniej, gdzie nad progiem znajduje się kunsztownie wyłożona luneta w kształcie podkowy, podobnie ozdobione jest północne wejście do kościoła. Natomiast z zachodniej strony fasadę bazyliki zdobi rzeźba w kształcie dwóch aniołów z „,krzyżem męczennika". W XVII wieku Katalikos Domenti odnowił bazylikę Anczischati, w tym czasie dobudowana została również dzwonnica, mieszcząca się kilka metrów na zachód od kościoła. W pierwszej połowie XIX wieku bazylika została ponownie odnowiona i pomalowana. Konserwatorzy usunęli warstwy późniejszych czasów, dzięki czemu zabytek przywrócony zostat do swojego oryginalnego wygladu (Beridze, 1976, s. 3-39).

Budynki krzyżowo - kopułowe znane są w Gruzji od VI wieku. Przypuszcza się, że jest to związane z wpływem monumentalnej architektury bliskowschodniej. Takie przypuszczenia powstają $\mathrm{w}$ związku z podobieństwem omawianych budynków z perskimi pałacami wcześniejszego okresu sasanidzkiego. Należy zauważyć, iż analogiczny styl znany był jeszcze za czasów starożytnej architektury gruzińskiej, przykładem służą cechy, które znajdujemy w budowlach typu ,darbazi”. Kopuła bazująca się na czworokącie powstaje w obiektach architektury gruzińskiej w tym samym czasie, kiedy po raz pierwszy ukazuje się ona w architektonice Bliskiego Wschodu. Budowle o krzyżowej kopule były różnego typu. Niektóre z nich w kształcie krzyża miały cztery wierzchołki na końcu każdego ramienia. Budynki innego typu miały tylko jedną absydę półkolistego kształtu, a pozostałe trzy miały prostokątny kształt. Ten typ budowli spotykamy w kościele należącego do kompleksu klasztoru Szio-Mgwime, który pochodzi z lat 50-60 VI wieku. Kościół Szio - Mgwime pod wezwaniem Jana Chrzciciela zbudowany w latach 80 VI wieku znajduje się na terenie klasztoru Szio-Mgwime w rejonie Mccheta na lewym brzegu rzeki Mtkwari, obecnie naprzeciwko dworca kolejowego Dzegwi. Klasztor został założony przez jednego z tak zwanych ,trzynastu asyryjskich ojców" - Shio będącego zakonnikiem eremitą nurtu „Mgwime”. Kopuła kościoła, będącego z początku pustelnią, jest do połowy wkopana w ziemię, co stanowi uhonorowanie autorytetu Szio Mgwimeli, który spoczywa na terenie klasztornym.

Plan kościoła przedstawia budowlę typu „wolny krzyż". Architektura tego rodzaju była szeroko rozpowszechniona w całym chrześcijańskim świecie. Centralny plac kopułowej świątyni pokrywa zamknięty łuk stojący na ośmiościennej rampie. Kościót charakteryzuje się surowymi i zwyczajnymi formami architektonicznymi, smuktymi proporcjami mas architektonicznych (Agababân, 1950), które w pełni odpowiadają ascetycznym nurtom. Kopuła, która jest półkulą, opiera się na ośmiościennej części wieży, tak zwanym bębnie wyposażonym w okna. Rodzaje bębnów w budynkach gruzińskich z czasem się zmieniały. Kościół Szio-Mgwime jest dość niski i szeroki. $W$ budynkach z późniejszych okresów wysokość bębna jest zauważalnie wyższa (Abramišvili, Zaharaâ, Cicišvili, 1944).

Dolina Apsów, zwana również „Koncha”, przyczyniła się do nadania nazwy „tetrakonchosu” architektonicznemu stylowi planowania czterolistnego. Do budynków wznoszonych na jego planie należy m.in. kościół Dzweli-Gawazi, świątynia w Ninotsminda, należąca do przejściowego etapu rozwoju architektury gruzińskiej. Katedra biskupia w została zbudowana w połowie VI wieku i jest to najwcześniejszy przykład, kiedy gruziński architekt zaimplementował niezwykle śmiałe zadanie oparte na tetrakonchosie. W ramach świątyni stworzono indywidualny całkowicie oryginalny architektoniczny styl, który nie został szerzej powielony w Gruzji, jak również nie znajdziemy podobnej budowli w Armenii czy Albanii. Świątynia Ninotsminda odegrała ważną rolę w rozwoju architektury gruzińskiej. Dziś w historiografii sztuki przyjmuje się, że twórca Ninotsminda swoim dziełem stworzył fundament wykorzystany w Światyni Krzyża w Mccheta oraz warunki do dalszego rozwoju tego typu zabytków.

Katedra Ninocminda położona jest 40 kilometrów na wschód od Tbilisi, w dzielnicy Sagaredżo, w centrum wioski Ninotsminda. Plan tej centralnie kopułowej budowli opiera się na skomplikowanej strukturze tetrakonchosu w kształcie gwiazdy. Strukturę tę można zaobserwować zarówno w organizacji przestrzeni wewnętrznej, jak i w zewnętrznych układach. Głównym zadaniem architekta Ninotsmindy było stworzenie przestronnej przestrzeni kopułowej. Aby osiągnąć ten cel, budowniczy przeciął narożniki centralnego placu i pomiędzy czterema apsydami odpowiadającymi kardynalnym punktom umieścił cztery pastoforia na przekątnej osi kościoła. W ten sposób udało mu się ułożyć osiem łuków kopułowych, na których postawił znacznie szerszą kopułę. W wyniku tej decyzji architekt zdołał znacząco zwiększyć średnicę kopuły i stworzyć rozbudowaną przestrzeń wewnętrzną. We wszystkich czterech częściach wnętrza znalazly się polożone naprzeciw siebie apsydy, jeśli zaś chodzi o ich cel funkcjonalny, po obu stronach ottarza maja sie mieścić oltarz i diakonnik (Abramišvili, Zaharaâ, Cicišvili, 1944).

Wnętrze świątyni było oświetlone przez okna, wycięte pod kopułą we wszystkich czterech absydach. Trzy okna znajdowały się w ołtarzu, natomiast pastoforii pozbawiono niezależnego źródła światła, docierającego jedynie z wnętrza kościoła przez drzwi, których świątynia miała siedem par. Głównym zadaniem architekta Ninocmindy była organizacja przestrzeni wewnętrznej, przez co na zewnętrzny wygląd nie zwrócono należytej uwagi. Na fasadzie wschodniej został położony akcent tylko na pięciobocz- 
nym występie ołtarza. Wszystkie inne apsydy i pastoforia stanowią niezbyt zrozumiałą i słabo wyraźną jedność elementów cylindrycznych, dlatego charakteryzują się one ciężkimi i szorstkimi formami, co podkreśla archaiczny wygląd świątyni. W XVIII wieku kościół był wielokrotnie odnawiany, okresie tym została otwarta brama od strony zachodniej. W 1825 r. świątynia została zniszczona przez trzęsienie ziemi.

Na wyższym poziomie wczesnośredniowiecznej architektury znajduje się słynna świątynia Dżwari w Mcchecie pod wezwaniem Podwyższenia Krzyża Świętego. Można powiedzieć, że architektura Dżwari podsumowuje etap gruzińskiej architektury pierwszych wieków chrześcijaństwa w Gruzji. W procesie jednoczenia kraju, kiedy w Kartli rządzili Erismtawrebi, architektura religijna osiągnęła tutaj znaczny wzrost. Genialny architekt Dżwari stworzył klasycznie zrównoważony, wyjątkowy typ architektury, stanowiący kulminację złożonego procesu twórczego poszukiwania gruzińskiej kopułowej architektury wczesnego średniowiecza. Duża świątynia Dżwari przedstawia fundament stylu klasycznego gruzińskiej architektury - na przełomie VI i VII wieku i przyczyniła się do rozpowszechnienia tego stylu architektonicznego w różnych regionach Gruzji. Świątynia Dżwari znajduje się na wschód od jednego z najstarszych miast Gruzji historycznej stolicy królestwa Iberii - Mccheta, na lewym brzegu rzeki Mtkwari, na szczycie góry. To właśnie w tym miejscu w latach 30 . IV wieku św. Nino i król Mirian wznieśli pierwszy krzyż, według legendy wyrzeźbiony z cedru wyrosłego na grobie Sydonii odzianej w szaty należące wcześniej do Chrystusa. Architektowi Dżwari udało się dopasować świątynię do ogólnej struktury kompozycyjnej monumentalnego masywu górskiego, na którym wzniesiono świątynię, w związku z tym jest ona postrzegana, jako organiczne połączenie $\mathrm{z}$ krajobrazem.

Obok niewielkiej świątyni Dżwari zbudowanej w czasie panowania Guarama Kuropalata, gdzie pod otwartym niebem stała wspólna świątynia Gruzinów, Ormian i Albańczyków, zwolennicy Guarama Kuropalata - patrikios Kartli Stefanos i Demetr Wipatos zbudowali całkowicie oryginalną świątynię kopułową. Według G. Chubinashvi$1 i^{2}$, poprzednikiem Dżwari jest katedra episkopalna w Ninocminda, gdzie po raz pierwszy powstała przestronna wewnętrzna przestrzeń z pastoforiami pod centralną kopułą. Architekt Dżwari dostrzegł nieścisłości budowy świątyni Ninocminda i osiągnął doskonałość swojej pracy z artystycznego i konstruktywnego punktu widzenia. Dzięki zupełnie nowej organizacji przestrzeni wewnętrznej, harmonijnej spójności mas architektonicznych, zrównoważonej symetrii, Dżwari jest przełomowym dziełem wczesnośredniowiecznej gruzińskiej architektury religijnej.

Podstawą planu Dżwari jest narożny tetrakonchos. $\mathrm{W}$ przeciwieństwie do katedry $\mathrm{w}$ Ninocminda, pastoforia znajdują się w przestrzeni wewnętrznej po obu stronach apsyd wschodniej i zachodniej, co spowodowało poja-

\footnotetext{
Giorgi Chubinashvili (21 listopada 1885 - 14 stycznia 1973 r.)gruziński historyk sztuki
}

wienie się dodatkowych elementów na tej osi, ponieważ bez nich nie byłoby możliwe zaplanowanie pastoforii po obu stronach świątyni. Decyzja ta doprowadziła do pewnych zaburzeń na osi centralnej, choć wizualnie nie jest to oczywiste. Na przekątnych kwadratu w przestrzeni wewnętrznej znajdują się wysokie nisze małej objętości, ich kontury na planie stanowią trzy czwarte koła. $Z$ jednej strony służą one jako wejście do pastoforii, a $z$ drugiej stanowią połączenie z pokojami narożnymi wewnętrznej przestrzeni świątyni. Według definicji G. Chubinashvili pastoforia mialy przypuszczalne cele funkcjonalne, gdzie po obu stronach ottarza znajdowat się diakonnik, a po obu stronach zachodniego ramienia byty przestrzenie dla kobiet oraz ksiazząt. Do miejsca, w którym staty kobiety lub nowo ochrzczeni, prowadzily dodatkowe drzwi (Čubinašvili, 1948).

Struktura przestrzenna świątyń wpisuje się w kwadrat, na którym wzniesiono ośmiościenną podstawę kopuły. Trompy umożliwiły przejście od kwadratu do okręgu otaczającego kontury koła. Duże trompy pierwszego rzędu przekształcają kwadrat $\mathrm{w}$ ośmiokąt, na nim umieszona została kopuła, w której wycięto cztery okna, nad którymi znajdują się dwa kolejne rzędy małych tromp. Za ich pomocą osiem kątów dzieli się na szesnaście, a ostatni rząd tromp zamienia szesnaście kątów na trzydzieści dwa, stanowiąc podporę dla półkulistej kopuły.

Świątynia ma dwa wejścia, które znajdują się na poprzecznej osi apsydy północnej i południowej. Rozwiązanie to umożliwia odwiedzającemu jednocześnie objąć wzrokiem całą wewnętrzną przestrzeń świątyni, która dzięki stopniowemu harmonijnemu włączaniu przestrzennych segmentów od góry do dołu reprezentuje się jako jednolity, zrównoważony organizm. Ołtarz we wschodniej części, jasno oświetlony trzema oknami, przecięty przez apsydę ołtarzową, jest postrzegany jako wyjątkowa dominanta na tle przestrzeni wewnętrznej. Wrażenie to wzmacnia stosunkowo słabsze oświetlenie trzech pozostałych ramion świątyni.

Główne wejście do kościoła - południowa fasada - jest ozdobione reliefowymi rzeźbami, wśród których wyeksponowana została rzeźba stanowiąca podstawę krzyża. Na ościeżach zewnętrznych drzwi wejściowych do tak zwanej ,żeńskiej części" dwa anioły podnoszą obraz Stwórcy wpisany w kłujący wieniec. Obok wysunięcia można rozpoznać styl Stefanoziego ${ }^{3}$, gdzie u podstawy kopuły znajduje się rzeźba klęczącego architekta Dżwari. Zachodnia i północna fasada Dżwari nie są ozdobione rzeźbą ani żadnym innym elementem dekoracyjnym. Powodem tego jest usytuowane północnej fasady przed dużą świątynią sprawiające, iż jest ona prawie niewidoczna dla zwiedzających oraz uniemożliwiające im dostęp do rzeźb. Tym samym praktycznym podejściem kierowano się przy ekspozycji zachodniej fasady, która wzniesiona na skraju gołej skały jest widoczna tylko z dużej odległości. Dzięki dekoracjom z łatwością ustalono okres, w którym świątynia została zbudowana (586/7-604). Zarówno w wewnętrznej prze-

\footnotetext{
Stafanozi - jeden z budowniczych Dżwari
} 
strzeni świątyni, jak i w jej zewnętrznym wyglądzie można zaobserwować logicznie wyrównane proporcje form doprowadzonych do wyrafinowanej perfekcji, symetrycznie zrównoważone układy architektoniczne, a zatem należą do klasycznych dzieł architektury. Budowniczowie wielkiego Dżwari umieścili w świątyni relikwię narodu kaukaskiego - krzyź świętej Nino, który stał się święty nie tylko dla chrześcijan, ale także dla niechrześcijańskich ludów Kaukazu.

W Gruzji w VII wieku powstawały inne konstrukcje architektoniczne na wzór Dżwari. Do nich należy Atenis Sioni w pobliżu Gori, kościół Dzweli Szuamta w Martvili. Podobne typy budynków znajdują się również na terytorium Armenii. Jednakże te ostatnie różnią się od gruzińskich proporcjami. Poza Gruzją i Armenią ten typ budynku nie występuje. Należy również zauważyć, że architektura gruzińska wczesnego średniowiecza jest architekturą o ściśle klasycznym stylu.

Od zeszłego stulecia Atenis Sioni przyciąga uwagę badaczy swoimi licznymi i wielojęzycznymi wzorami epigraficznymi. Większość inskrypcji stanowi język gruziński, znajdują się tam również napisy ormiańskie, greckie, syryjskie, arabskie, perskie, żydowskie, które wskazują na intensywne życie historyczne regionu. Plan świątyni oparty jest na kwadracie z czterema absydami zorientowanymi na cztery strony świata, co umożliwiło wyposażenie przestrzeni wewnętrznej zgodnie z zasadą tetrakonchosu. Przejście od kopulastego kwadratu do okręgu odbywa się w trzech rzędach tromp, gdzie kwadrat, podobnie jak w Dżwari jest podzielony na 32 kąty. Otwory drzwi $\mathrm{z}$ pastoforii znajdują się w niszach, jedynym wyjątkiem jest budynek południowo-zachodni, który, podobnie jak Dżwari, ma drzwi skierowane na zewnątrz. Umieszczenie po obu stronach ołtarza i apsydy czworokątnych pastoforii usytuowanych naprzeciw niej na osi wschód-zachód doprowadziło do potrzeby urządzenia przegród. W związku z powyższym, tak jak w pierwowzorze Dżwari, centralna struktura wewnętrznej przestrzeni została nieco zaburzona. Organizacyjnym łącznikiem architektury jest ciężka, masywna kopuła, na której znajduje się płaskorzeźba zwana „krzyżem męczennika”.

Strukturę przestrzeni wewnętrznej podkreślają architektoniczne tablice świątyni z szerokimi półkami i głębokimi wnękami. Ponieważ nie ma niszy na zachodniej fasadzie Dżwari stojącej na skalistym klifie, zachodnia fasada Sioni również została wzniesiona bez nisz, pomimo iż znacząca jej część dziedzińca przylega do świątyni i jest ona dobrze widoczna. Rzeźby reliefowe umieszczone na wszystkich czterech fasadach przy kopule są w większości chaotycznie rozproszone. Jedynie na występie wschodniej fasady są słabe podobieństwa rzeźb Dżwari, ale nawet tutaj nie znajdzie się proporcjonalnego rozkładu, który widoczny jest w Mcchecie. Niemniej jednak badania świątyni potwierdziły, że twórca Atenis Sioni starał się nie tylko naśladować architekta Mcchety, tworząc kopię Dżwari, ale również dokonał pewnych zmian w organizacji wewnętrznej przestrzeni i struktury zewnętrznych układów. W pewnym stopniu zmienił harmonijną strukturę pierwowzoru trompy oraz spróbował osiągnąć iluzję rozszerzenia przestrzeni wewnętrznej. Te zmiany spowodowały zmniejszenie ilości światła wpadającego do wnętrza w porównaniu do Dżwari. Udało się ustalić, że budowniczymi Atenis Sioni byli Waraz - erismtawari ${ }^{4}$ Kartli, jego syn - Nerse, który jest wymieniony w kronice „Nawrócenie Kartli” jako „wielki eristmtawari”, syn Nerse - Stepanos - „Erismtawari z Eristawów Gruzinów i Megrelów", reprezentujący młodsze pokolenie. W drugiej połowie X wieku rzeźba erismtawari Nerse została ponownie wyrzeźbiona i zainstalowana w miejscu rzeźby Nerse i Stepanosa, zastępując jej poprzedniczkę.

W trakcie wykopalisk archeologicznych na terenie Sioni odkryto resztki starożytnego kościoła pod świątynią. Jest to charakterystyczne dla bazyliki typu architektonicznego o najstarszej strukturze, która rozwija się wzdłuż osi podłużnej i jest o trzy metry dłuższa niż obecna długość Sioni, co umożliwia identyfikację jej pierwotnego stanu. Fundament, na którym stoi dziś kopulasta świątynia, została początkowo wybudowana dla bazyliki Sioni. Data powstania starożytnego kościoła i jego platformy została ustalona dzięki grobowcowi osadzonemu w podstrukturze - glinianym sarkofagu. Wiadomo, że takie gliniane sarkofagi w Kartli były używane tylko w IV-V wieku, a ich stosowania zaprzestano w VI wieku. Różne elementy architektury pierwotnego kościoła, odkryte podczas wykopalisk, pozwalają na szacunkowe datowanie budowy kościoła w połowie $\mathrm{V}$ wieku. Wykopaliska potwierdziły przypuszczenie Iwane Dżawahiszwili ${ }^{5}$, twierdzące, iż pierwotnie bazylika Atenis Sioni została wybudowana ku czci Spoczęcia Bogurodzicy.

Od połowy X wieku w sakralnej architekturze okresu feudalnego nastąpiła zmiana jakościowa. Twórcy tej epoki byli dobrze zaznajomieni z osiągnięciami poprzedniej, ale mimo to weszli w nową erę poszukiwań inspiracji. Ich innowacje wyraźnie wskazują na wiedzę opartą na arcydziełach z przeszłości i twórcze zrozumienie cech wspólnych. To niezwykłe, że takie podejście do problemu nie jest jedynie lokalne, charakterystyczne dla wyodrębnionego regionu, przez co odczuwalne jest terenie całego kraju. Nowe spojrzenie na styl rozpowszechnia się w całej Gruzji. Z jednej strony motyw bazyliki pochodzący z V wieku wciąż przypomina sobie, ale dla nowych twórców to nie stanowi ograniczenia. Nadal budują duże i wysokiej jakości trójnawowe kościoły, przy czym jednocześnie wyraźnie widać, że motyw bazyliki nie przeszkadza im wiernie podążać za nowymi wyzwaniami. Architekci tej epoki mieli obsesję na punkcie nowego stylu.

Najbardziej bogate pod względem rozwoju rodzajów i typów gruzińskiej architektury średniowiecznej są dwie epoki: pierwsza - VI-VII wiek, druga zaś - wiek X-XI. Niewyczerpana fantazja architektów gruzińskich tego okresu odbija się w rozmaitości zachowanych budynków.

\footnotetext{
Erismtawari - władca

Iwane Dżawachiszwili (ur. 11 kwietnia 1876 w Tbilisi, zm. 18 listopada 1940 tamże) - gruziński historyk i językoznawca
} 
$Z$ jednej strony są tu obficie reprezentowane kompozycje, mające jako podstawę podłużny krzyż, a $z$ drugiej zaś strony znajdują się też przykłady kompozycji z mnóstwem apsyd, zbliżających się do kręgu. Pierwsza kategoria zaczyna się w Oszki; druga zaś - z Kumurdo. Obydwa budynki wzniesione zostały w latach 60 . X wieku. W ciągu następnych 50-60 lat formy te się zmieniają. Pierwsza kompozycja, bazująca się na osi podłużnej, była używana przez dłuższy czas; druga zaś, dążąca do kręgu, istniała tylko przez 60-70 lat.

Wśród sakralnych budynków wzniesionych w okresie wczesnego feudalizmu znajdują się największe katedry, które reprezentują nie tylko własną epokę, lecz całą średniowieczną Gruzję. Są to świątynie: Oszki w Tao-Klardżeti i Bagrati w Kutaisi. Nie tylko przestrzeń czasu, ale także ideologiczna jedność dość odległych regionów Gruzji przejawiają się w tych wielkich pod każdym względem zabytkach, co jest bardzo interesujące z punktu widzenia integralności kraju. Pierwszy z nich, Oszki, stoi na przedmieściach Gruzji Południowej w Tao, drugi znajduje się w ówczesnym centrum administracyjnym i kulturalnym Kutaisi. Pomimo odległości ich dzielącej owe kościoły, wspólny styl jest wyraźnie widoczny.

Księstwo Tao-Klardżeti zajmowało szczególne miejsce w podzielonej Gruzji z okresu IX-X ww. Pierwsze odrodzenie, zarówno w życiu politycznym, jak i we wszystkich sferach kraju, po okresie najazdu arabów zaczęło się właśnie w Tao-Klardżeti. Nastąpił okres wielkiego rozwoju w architekturze, malarstwie ściennym, rzeźbie i wielu innych dziedzinach. Ożywienie to było bezpośrednio związane $\mathrm{z}$ procesem formowania nowego państwa gruzińskiego. U źródeł zakorzenienia kultury oraz monastycyzmu stała tak ważna postać, jak Grigol Chancteli ${ }^{6}$ (759861). Ten wybitny myśliciel i twórca stał się inicjatorem i przewodnikiem wielu ważnych przedsięwzięć. Miał pozytywny wpływ na takie ważne osobistości polityki jak Aszot Kuropalat i jego następcy. Walka tej nowej gałęzi Bagrationi o powstanie suwerennego kraju i jego zjednoczenia ujawniły bezprecedensowy potencjał, którego żadne siły zewnętrzne nie mogły powstrzymać, a tym samym zatrzymać procesów, które się rozpoczęły. Rezultatem działalności Grigola Chancteli, oczywiście przy wsparciu Aszota Kuropalata ${ }^{7}$, było założenie tak dużych ośrodków klasztornych, jak Chandzta, Opiza, Szatberdi i inne (Zakaraia, 1990).

Świątynia Oszki jest pierwszą ze średniowiecznych kościołów, w której wyraźnie objawił się powiew nowej ery. Proporcje tutaj są wysokie, majestatyczne, w porównaniu z poprzednimi wiekami, doskonałość i moc architektury są tu wyraźnie zaakcentowane. Należy również podkreślić, że genialny architekt Oszki ostatecznie utworzył nowy system projektowania fasad, mający znaczący wpływ na kolejne pokolenia architektów. Chronologiczną kontynuacją wznoszenia budynków sakralnych tego rodzaju jest świątynia Bagrati w Kutaisi, która została

\footnotetext{
Grigoła Chancteli - święty gruziński mnich żyjący w VIII w.

Aszot I Kuropalat (?-29.01.826) król gruziński (od 809 r.)
}

wzniesiona przez króla Bagrata III $^{8}$. Po stronie głównego okna na elewacji północnej znajduje się napis: „Po ułożeniu podtogi byt to 223 rok od koronacji”. Jeśli przełożyć tę datę na kalendarz chrześcijański wskazana data przypada na 1003 rok. Wnioskować z tego można, że budowę świątyni rozpoczęto pod koniec $\mathrm{X}$ wieku i najwyraźniej ukończono ją w okresie bliskim 1003 roku. Powyższy przykład jest interesujący pod tym względem, iż cyfry arabskie dotąd niestosowane w inskrypcji gruzińskiej zostały użyte po raz pierwszy. Budowa tak wspaniałej świątyni króla Bagrata wzrosła swoim znaczeniem do poziomu państwowego, gdzie monarcha zapraszał sąsiednich władców, katolikosów, wyższych duchownych i wielu znamienitych ludzi, nie mniej tak majestatyczna katedra niewątpliwie godna takich zaszczytów. Niefortunnie ten wspaniały pomnik historii sakralnej, choć przetrwał do czasów obecnych, został przed wiekami poważnie uszkodzony. Tureccy zdobywcy wysadzili go w powietrze w 1691 roku, w wyniku czego kopuła i podłogi całkowicie się zawaliły. Katedra została wzniesiona na lewym brzegu Rioni na wysokiej górze. Jego początkowa struktura składała się trzech naw, jednak w przeciwieństwie do Oszki cała struktura została zamknięta $w$ jednym prostokącie, a jedynie apsydy są przedstawione w postaci występów. W przestrzeni obok apsydy ołtarza znajdują się diakonnik i ołtarz. Zachodnie ramię wyróżnia się różnorodnością, gdzie jego front jest trójnawowy. Komory znajdowały się na drugim poziomie naw bocznych. Wewnętrzna przestrzeń była zwieńczona kopułą opartą na czterech potężnych wieżach. Nawet pomimo silnych zniszczeń świątynia Bagrat pozostawia niezatarte wrażenie na obserwatorze swoją imponującą monumentalnością. W ostatnich latach znaczna część elewacji została odrestaurowana. Niezwykły kunszt budowniczego przejawiał się również w dekoracji fasad z ciągłymi łukami. Pierwotne oblicze świątyni w zewnętrznych układach architektonicznych można wizualnie ujrzeć tylko we wschodniej części. Po stronie zachodniej, poczynając od wyeksponowanych części bocznych, występuje wiele późniejszych zmian wynikających z rozbudowy. Pozycjonując chronologicznie, pierwsza została wybudowana wieża w północno-zachodnim rogu. Przypuszczalnie została ona wzniesiona tuż po wybudowaniu świątyni. Wkrótce do świątyni dodano niezwykle wdzięczną bramę z południa i północy. $\mathrm{W}$ porównaniu $\mathrm{z}$ budynkiem głównym projekt bramy wygląda na znacznie bogatszy i bardziej urozmaicony, a rzeźby i płaskorzeźby wniosły harmonię w odbiorze estetycznym. Jednak budowa świątyni nie zakończyła się na tym, w późniejszym okresie zachodnia część została uzupełniona otwartymi galeriami przez linię apsyd. Ten nowy element architektoniczny w planie dekoracyjnym znajduje się u szczytu możliwości swojej epoki. Należy podkreślić, że świątynia Bagrata jest dziełem sztuki na najwyższym poziomie, jest chlubą narodu gruzińskiego, przy czym w 1994 roku katedra została wpisana na Listę Światowego Dziedzictwa UNESCO. Jednakże wbrew

\footnotetext{
8 Bagrat III (ok. 960 - 7.05.1014) król gruziński z dynastii gruzińskiej Bagrationi
} 
regułom tejże organizacji w roku 2008 rozpoczęto rekonstrukcję świątyni, co poskutkowało usunięciem katedry z Listy UNESCO.

Podczas drugiego etapu rozkwitu architektury gruzińskiej szczególnie przejawia się potencjał twórczy architektów gruzińskich. Podobny rozwój twórczy obserwujemy od samego początku X wieku, jednak jego szczyt przypada na połowę stulecia oraz na pierwszą połowę wieku następnego. Początkowo rozwój toczy się w różnych kierunkach, ale w końcu na arenie architektonicznej pozostają tylko trzy typy konstrukcji. Są to budowle na planie tetrakonchosu, wieloapsydowe oraz cerkwie centralno-kopułowe. Najbardziej efektowne wśród tych konstrukcji są cerkwie wieloapsydowe. W ciągu niespełna stulecia konstrukcje tego typu osiągnęły szczyt własnego rozwoju. Studiując plan, kompozycje, ozdobę itp. można wnioskować, iż architekci gruzińscy stale starali się stworzyć coś nowego. Należy również dodać, że każda nowa idea architektoniczna błyskawicznie docierała do każdego zakątku kraju. Jeżeli pierwowzór budynku wieloapsydowego jest datowany rokiem 964, to budowa ostatniej cerkwi tego typu przypada na lata 1010-1014 (Amiranašvili, 1944).

Zbudowane w tym okresie oraz zachowane do dzisiaj kościoły geograficznie położone są w paśmie: Kumurdo - w Dżawacheti; Gogiuba, Oltisi, Kiagmis-Alti, Taoskari w Tao-Klardżeti; Boczorma - w Kacheti; Kacchi - w Imereti; Nodżichewi - w Samegrelo. Nie wiadomo natomiast ile spośród zabytków nie przetrwało upływu czasu. Jeśli wziąć pod uwagę, jakiego rodzaju transportu używano w tamtych czasach oraz prędkości przemieszczenia się, tempo i skala rozpowszechniania idei architektonicznych są nad wyraz imponujące. Należy podkreślić, że wszystkie elementy kościołów apsydowych są zarodkami wyodrębnionego stylu malarskiego. Wymagania nowego stylu wpłynęły na dynamiczne plany z ruchomymi liniami, śmiałymi kompozycjami wewnętrznymi i zewnętrznymi oraz na pojawienie się pomysłu wkomponowania rzeźby do płaskorzeźby.

W procesie poszukiwania genezy kościołów wieloapsydowych należy spojrzeć wstecz. Tło ich występowania należy szukać w tetrakonchosach, jednak byłoby błędem rozpatrywać bezpośrednie połączenie między nimi. Idea kościołów apsydowych powstała pod koniec okresu przejściowego rozwoju architektury gruzińskiej i wkrótce, na początku XI wieku, zakończyła swoje istnienie. Każdy z kościołów zbudowanych w tym okresie jest niepowtarzalnym, niezależnym dziełem. Niemniej jednak można je pogrupować według wspólnych cech i warunkowo podzielonych na trzy grupy: pierwsza grupa to kościoły o pięciu apsydach (Kumurdo, Nikortsminda), druga - kościoły 6-absydowe (Gogiuba, Oltisi, Kiagmis-Alti, Boczorma, Kacchi), a trzecia - 8-apsydowe (Nodżichewi i warunkowo Taoskari).

W literaturze z zakresu historii sztuki kościoły Kumurdo i Nikorcminda nazywane są sześcioapsydowymi, mimo że w rzeczywistości posiadają pięć absyd w typie konchosu i jedno prostokątne ramię. Faktem jest, że znajduje się w nich po sześć podpór kopułowych.
Świątynia Kumurdo, położona w Dżawacheti, w rejonie Achalkalaki, jest pomnikiem datowanym na 964 rok. Należy zwrócić uwagę, iż jest to rzadki przypadek, gdy znane są zarówno personalia zamawiającego budowę, króla, za panowania którego ma to miejsce, jak i samego autora projektu. Istotne jest to zwłaszcza ze względu na to, że w przypadku Gruzji jest to bardzo rzadkie zjawisko, dotyczące szczególnie architektów. Ze względu na skromność zostawali nimi często anonimowi artyści, którzy nie przekazywali informacji o sobie i swoich działaniach. Na ścianach świątyni znajduje się kilka napisów, wśród których główna informacja historyczna zawiera zapis nad południowymi drzwiami. Źródła traktują o tym, że w czasach cara Abchazji Leona, który był jednocześnie erismtawari Kartli, świątynia została zamówiona przez biskupa Ioane i zbudowana przez architekta Sakotsari.

W Kumurdo kontynuowano budowę również w późniejszym okresie, o czym informuje nas napis na łuku południowego przedsionka mówiący, iż za czasów króla Bagrata IV (1027-1072) wzniesiono południową kruchtę świątyni. Z innych napisów należy zwrócić szczególną uwagę na ten, który znajduje się nad zachodnim wejściem. Dzięki niemu dowiadujemy się, że w XVI wieku kościół został uszkodzony do takiego stopnia, że zawaleniu uległa jego kopuła. Podczas odbudowy świątyni zachodnie ramię zostało wzniesione ponownie bez uwzględnienia jego oryginalnych form. Przez całe średniowiecze biskupstwo Kumurdo cieszyło się wielką sławą. Niestety pomnik Kumurdinski dotrwał do czasów obecnych w zniszczonym stanie. Posiada on uszkodzoną kopułę i odbudowane zachodnie ramię.

Architekt Kumurdo - twórca i innowator, z jednej strony opierał się na tradycji, jednakże z drugiej, podobnie jak autor Oszki, wprowadzał nowy malarski styl. Podejście to trwało przez wieki i przetrwało całe epoki. Kumurdo jest tworem charakterystycznym dla późniejszych czasów. To przykład, a zarazem duma poczatkowego okresu nowego stylu (Severov, Čubinašvili, 1947). Pod względem architektonicznym widoczne jest podobieństwo Kumurdo i Oszki. Pomimo faktu, iż świątynie należą do różnych typów konstrukcji, wykazują wspólne rozwiązania oraz elementy budowy. Być może wynika to z faktu, że oba zabytki znajdują się w tym samym regionie - w południowej Gruzji. Nie jest wykluczone również, że obaj architekci byli członkami tego samego artelu lub jednego ze stowarzyszeń budowniczych. Wiadomo natomiast, że budowe Oszki rozpoczęto w 963 r., a Kumurdo - w 964 roku (Severov, Čubinašvili, 1947).

W drugim okresie rozwoju architektury gruzińskiej pojawia się wiele nowych rodzajów i typów konstrukcji budowlanych. Szczególnym jest typ kościołów centralnokupołowych, którego przykładem są dzieła architektów Samtawisi i Samtawro. Zgodnie z zachowanym historycznym napisem, świątynia Samtawisi pochodzi z 1030 roku. Samtawro nie posiada dokładnej daty budowy, jednak sądząc po cechach szczegółowych i stylu, kościół ten został wzniesiony w tym samym okresie co Samtawisi. Pozwala to stwierdzić, iż za założycieli nowego typu architekto- 
nicznego należy uznać obu autorów. Architekci Samtawro i Samtawisi opracowali tak nieskazitelny standard architektoniczny, że się on wzorem dla przyszłych pokoleń budowniczych. W ciągu następnych ośmiu wieków w Gruzji nie powstał inny styl kościołów kopułowych, czego przyczyną jest przede wszystkim doskonałość tego architektonicznego rozwiązania. Jednakże stwierdzenie, iż styl ten dominuje przez przeszło osiemset lat, nie oznacza ślepego powtarzania standardu, a jedynie wskazuje na wzorowe przestrzeganie zasad architektonicznych i zachowanie wyglądu jako całości. W rzeczywistości każde dzieło architektury odzwierciedla własna epokę i często można zauważyć wyraźna różnicę nawet o kilka lat (Amiranašvili, 1944). Naturalnie, pojawienie się tego typu architektury jest wynikiem stylu malarskiego powstałego w tej samej epoce. Plany kościołów, kompozycja wnętrza i struktur zewnętrznych, ogólny wystrój, rzeźba i plaskorzeźby - wszystko to jest jednoznacznie podporzadkowane nowemu stylowi (Agababân, 1950). Plany takich kościołów są wpisane głównie w prostokąt. Po stronie wschodniej ołtarz pozostaje trzyczęściowy, podobnie jak w świątyniach z wcześniejszego okresu, jednakże środek konstrukcji jest nieco przesunięty w stronę ołtarza. Taka zmiana została zaproponowana przez autora Cromi w pierwszej połowie VII wieku, kiedy cztery niezależne filary przedstawiały sobą wsparcie kopuły. W tym przypadku dwie z podpór kopułowych łączą się z rogami ołtarza. Co więcej, we wszystkich kolejnych stuleciach kopuła zaczęła opierać się na rogach ołtarza i dwóch zachodnich filarach. Należy tutaj zauważyć, że w gruzińskich kościołach kopułowych kopuła znajduje się pośrodku osi wschód-zachód lub usytuowana jest na wschód od niej. Osią kompozycji wnętrza jest centralna kopuła utworzona pomiędzy czterema ramionami krzyża.

Boczne pomieszczenia ołtarza z reguły są dwupoziomowe. Na dole znajduje się diakonnik i ołtarz, na górze - schowki, służące do przechowania świętych relikwii. Po bokach zachodniego ramienia znajdują się wąskie nisze, niekiedy nad nimi znajdować mógł się kliros. Oświetlenie wewnętrzne podlega również zasadzie kompozycyjnego eksponowania malowideł. Zazwyczaj w kościołach kopułowych przestrzeń pod kopułą jest lepiej oświetlona niż inne jej części. Architekci starali się ukazać wewnętrzną przestrzeń odwiedzającemu kościół w sposób jak najbardziej atrakcyjny. Aby osiągnąć ten cel, drzwi umieszczane były zarówno od strony zachodniej, jak również po bokach. Jednakże projektanci świątyń rzadko korzystali z tego rozwiązania. Najczęściej umieszczali oni drzwi nie w punkcie centralnym, ale bardziej stronie zachodniej w bocznych niszach.

Obserwator wchodzący do kościoła znajdował się w półmroku, podążając $\mathrm{w}$ głąb świątyni dostrzegał wnętrze w kontrastujących kolorach, natomiast znajdując się centrum świątyni spoglądając $\mathrm{w}$ dowolną stronę widział różnorodne barwy światła. Dekoracje fasad w tamtych czasach, w szczególności w świątyniach tego typu, zostały wzniesione do zenitu. Tutaj równie ważnym elementem jest arkada, która obejmuje wszystkie cztery boki struktury i rozciąga się ku górze. Ta metoda projektowania zostata wyraźnie określona w latach 60. X wieku i była używana przeszło przez dwieście lat. Ostatni raz spotykamy podobne rozwiazanie w światyni Ikort, pochodzacej z 1172 roku (Beridze, 1976).

Założenie klasztoru Gelati wiąże się z imieniem wielkiego króla gruzińskiego Dawida Agmaszenebeli (Budowniczego). Jeden z historyków pisze na ten temat: „,Dawid rozpoczą budować klasztor, a wybrat najpiękniejsze i najwspanialsze miejsce, na którym, podobnie jak drugie niebo, zamknat sklepienia światyni na cześć Świętej Matki Bożej". W istocie miejsce to jest uważane za najpiękniejszy zakątek Imereti, położony w okolicach Kutaisi, Kronikarz kontynuuje opowieść o tym, jak król sprawił, że to niebiańskie miejsce rozkwitło na zboczu góry oraz to jak zebrał w „drugim Jeruzalem” wybitnych wschodnich przedstawicieli tamtej epoki, uczonych i innych, którzy mieszkali w Gruzji i poza nią. Powszechnie wiadomo, że pośród nich znalazł się genialny filozof Joan Petritsi. Ich nazwiska są silnie związane z Akademia Gelati. Budynek akademii, wraz z innymi kościołami i dzwonnicą do dziś zdobi zespół architektoniczny Gelati. W miejscu tym, na dziedzińcu spoczywa sam król Dawid. W związku z budową świątyni król Dawid Agmaszenebeli wyraził swoją wolę, mówiącą że „Pozostat klasztor, mój grób i grób moich dzieci, niedokończonym, a ja zabieram ze sobq wieczna tęsknotę. Niech mój syn Dimitri dokończy go na zawsze dla mnie, dla siebie i dla mojego potomstwa". Jak wskazują źródła historyczne, król Dawid rozpoczął budowę tych „,drugich Aten” i „,drugiej Jerozolimy” w 1106 roku. Kiedy zmarł (1125), katedra nie była jeszcze ukończona. Świątynia Gelati pozostała dobrze zachowana, we wszystkich okresach jej istnienia służyła nie tylko jako ośrodek kulturalny, naukowy i duchowy, ale również przedstawiała jedno z głównych osiągnięć narodu gruzińskiego. Wśród wielu dzieł sztuki znaczenie klasztoru podkreśla zachowana ikona Matki Bożej Chachuli. Majestatyczna katedra w Gelati jest wielowarstwowa. Główna świątynia centralnokopułowa przetrwała do dziś w doskonałym stanie. Przestrzeń wewnętrzna jest przestronna, a jej kompozycję łączą ramiona krzyża, z których tylko ramię wschodnie jest absydą. Źródła światła są rozmieszczone po czterech stronach. Światło dociera do środka głównie z 16 okien wyciętych w kopule.

Absydy są charakterystyczne głównie dla zachodniej Gruzji we wczesnym średniowieczu, ale zdarzały się wyjątki również w późniejszym okresie. Współcześnie nie istnieje możliwość uświadczenia ówczesnego oblicza katedry, ponieważ jej dolna część jest przykryta przez dobudowy, które powstały w XII-XIII wieku, jednakże sama pierwotna zasada projektowania została zachowana. Autor świątyni dokładnie opanował metodę projektowania fasady, przyjętą od pierwszej połowy X wieku do połowy XI wieku. Udało mu się, nie zaburzając oryginalnych planów, wprowadzić własne koncepcje. Wnętrze kościoła, jak również później dobudowane sanktuaria są w całości pomalowane, znajdujące się tam obrazy pochodzą z XII-XVII wieków. Wśród fresków znajdują się jedyny zachowany do dzisiejszych czasów obraz króla Dawida, jak również 
Bogurodzica z Archaniołami przedstawiona na sklepieniu apsydy, która jest dziełem uważanym za ostatni przykład gruzińskiego malarstwa mozaikowego, stworzonego w drugiej połowie lat dwudziestych XII wieku (Čubinašvili, 1936).

Gruzja od początku istnienia otoczona byłą wrogimi jej państwami i plemionami, jednakże na szczególną brutalnością wykazali się Mongołowie. W latach 20. XIII wieku ten przybyły ze wschodu bezlitosny wróg pustoszył poprzez mordy i rabunki dobrze prosperującą Gruzję. Przez dwieście lat inwazje mongolskie zniszczyły zarówno integralność kraju, jak również wpływały na zauważalny spadek gospodarczy. Pomimo tego wyzwania gruzińscy władcy wbrew przeciwnościom wciąż kontynuowali rozwój architektury sakralnej. Działo się tak nawet wtedy, gdy wrogowie zalali kraj, doprowadzając do jego rozdziału na trzy części: Zachodnią, Wschodnią Gruzję i Samtsche historyczny autonomiczny region. Z sakralnych zabytków tego okresu należy wyróżnić: Metechi - w Tbilisi (odrestaurowany niemal od nowa na swoim dawnym miejscu); Sapara, Zarzma, Chule, Bieti, Tisseli - w Samtsche; Chobi, Mgwimewi, Csaiszi, Bedia (przebudowany) - w zachodniej Gruzji; Gergetis Sameba - w Gergeti; Sabacminda (w Kardanachi), Saczino (w pobliżu Zemo Chodasheni) - w Kacheti i inne. Porównując zabytki z tego okresu z wcześniejszymi, łatwo można zauważyć, jak dramatycznie spadł poziom architektury $\mathrm{w}$ ciągu zaledwie stu lat. Zanikowi uległy ekspresyjne formy, wyrafinowane ozdoby, charakterystyczne dla poprzednich stuleci. Regres polityczny i gospodarczy boleśnie wpłynął na rozwój architektury. Rozpoczęła się recesja, która stała się szczególnie widoczna pod koniec XIV wieku. Pomimo iż zabytki sakralne $\mathrm{z}$ tej epoki są bogate $\mathrm{w}$ rzeźby brak w nich ekspresyjnych dekoracji charakterystycznych dla poprzednich czasów. Rzeźbione ornamenty z XI wieku zadziwiają wielokolorową inwencją, umiejętnością rysowania, swoją głębią i wirtuozowską grą światła i cienia. Jednakże podobne koncepcje nie są już spotykane w późniejszych okresach. Trudno dostrzec dawna mnogość motywów kwiatowych, które wcześniej dominowaty $i$ zostaty zastapione bryłami geometrycznymi. Ogólnie rzecz biorąc, wybór motywów staje się gorszy, a rzeźba jest spotykana coraz rzadziej (Zakaraia, 1990). Dopiero w XV wieku kraj dotąd pogrążony w chaosie i dewastowany przez najazdy Mongołów zaczął odbudowywać poczynione zniszczenia.

Do ww. epoki należy Metechi (Tbilisi) świątynia, która uległa wielkim zmianom i przetrwała do dziś w takim obliczu, iż ciężko jest przypisać ją do konkretnego stylu architektonicznego. Źródła nie podają konkretnych informacji dotyczących świątyni, mimo że wiąże się z nią wiele starożytnych legend. Jedna z nich przypisuje budowę pierwszego kościoła w tym miejscu królowi Wachtangowi Gorgasali. Według innej legendy grób męczennicy Szuszanik, żony namiestnika Warskena, znajduje się w diakonniku klasztoru Metechi, chociaż według wszystkich innych źródeł została ona pochowana w Curtawi. Wzmianki o kościele Matki Boskiej Metechi, zwanym potocznie Metechi, spotykamy na łamach kronik jako budowlę z XII wieku. W czasie panowania Tamar pobudowano świątynię, w której modliła się królowa. Podczas zbrojnego wypadu Mongołów w 1235 r. dowódca garnizonu w Tbilisi spalił fortecę, a pałac i świątynia zostały zniszczone. Wkrótce pałac zostal odbudowany wraz ze światynia, która zostata przywrócona do swej dawnej świetności przez Dmitrija, poświęcono ja w latach 1278-1289, pomimo tego jeszcze przez wiele stuleci Metechi spotykat ciężki los. Wreszcie, w 1748 r. król Herakliusz II pokonat najeźdźców, więc przywrócenie nie tylko twierdzy, ale także światyni wiąze się również z jego imieniem (Zakaraia, 1990).

Ostatnie trzy stulecia Gruzji feudalnej - to najtragiczniejszy okres jej historii. Przebywanie przez dwa stulecia pod jarzmem mongolskim negatywnie odbiło się na kulturze kraju. Gruzja stała się słabsza politycznie i ekonomicznie, w dodatku powstały dwa sąsiednie imperia - niegdyś stosunkowo słaba Persja, która powoli staje się coraz silniejszy pod rządami dynastii Safawidów, oraz imperium Osmańskie, które dosłownie pochłonęło potężnego chrześcijańskiego sąsiada Gruzji - imperium Bizantyjskie. Obydwa mocarstwa pragnęły opanować Gruzję.

Jednak nawet $\mathrm{w}$ tak skrajnych warunkach sztuka gruzińska nadal się rozwijała. Pomimo stosunkowego osłabienia i wyodrębnienia się poszczególnych regionów Gruzji oraz staraniach odbudowy kraju w XV wieku zrujnowanego przez mongolskie najazdy, już w XVI w. widać znaczący progres oraz wejście $\mathrm{w}$ nową epokę w budownictwie sakralnym, choć nie jest on porównywalny z poprzednimi epokami rozkwit architektury gruzińskiej. Pomimo ciężkiej sytuacji dotykającej Gruzji z tamtych czasów oraz częściowych podziałów na odrębne królestwa i księstwa, zauważalny staje się miejscowy zintensyfikowany rozkwit kultury. Przede wszystkim dotyczy to Kacheti, które powstało jako niezależne królestwo, a następnie Kartli oraz zachodniej Gruzji. W przeciwieństwie do Europy Zachodniej, kraj ten wciąż pozostaje feudalny, podobnie architektura odnosi się do znanych już kierunków.

Gruzja w XIII-XV wieku znajdowała się w niewyobrażalnie trudnej sytuacji, jednakże już w XVI wieku sytuacja zaczynała skłaniać się ku lepszemu. Odrodzenie narodowe jest odczuwalne na całym froncie kulturowym, dotyczy to zwłaszcza poezji. W epoce tej tworzą tacy wielcy poeci, jak Teimuraz I, król Arczil, Dawid Guramiszwili, Besiki (Bessarion Gabaszwili) i in. Po latach gruzińskich zmagań z ofensywą mongolską, nadszedł czas na odbudowę kraju i rozwój, który był wyraźnie widoczny w architekturze, w malowaniu fresków, w ręcznie pisanej miniaturze książek, w biżuterii itp. Powstaje wtedy wiele dużych i mniejszych budowli, w tym sakralnych, jednakże jako przykłady sztuki są one dalekie od wysoce artystycznych dzieł wczesnego okresu. Należy zauważyć zaskakującą odporność i elastyczność Gruzinów, którym udało się utrzymać jedność narodową w szerokich warstwach kultury. Gruzja stanowi oryginalne tło zarówno pod względem stylu architektonicznego, jak i zastosowanych materiałów budowlanych. Późny okres gruzińskiej architektury średniowiekowej charakteryzuje się strzelistym kierunkowa- 
niem świątyń ku niebu, pod względem materiałów można zauważyć szerokie zastosowanie cegieł, a także brył.

W dekoracji fasad można częściowo zauważyć przywrócenie niektórych rozwiązań kompozycyjnych. W szczególności wśród takich elementów należy zwrócić uwagę na łuki. Prawdą jest, że te konstrukcje nie są tak wyraziste, jak w XI-XII wieku, ale mimo to łuki stają się głównymi elementami dekoracji fasad. Przykładami wspomnianego stylu są m.in. Ananuri, Gremi.

Świątynia w Ananuri jest słynnym pomnikiem ostatniego okresu feudalnej Gruzji. W regionie nie powstało wiele świątyń o większych rozmiarach i wyróżniających się wyższym poziomem w kategorii artystycznej. Podobnym kunsztem odznacza się twierdza będąca rezydencją książąt Aragwi, Eristawi. Jest to jedyna konstrukcja, która zachowała się do naszych czasów w stanie nienaruszonym. Ananuri znajduje przy szlaku Gruzińskiej Drogi Wojennej, około sześćdziesięciu kilometrów od Tbilisi, wzdłuż prawego brzegu rzeki Aragwi, u zbiegu z rzeką Wedzatchewi. Świątynia ta uważana jest za przykład gruzińskiej architektury fortyfikacyjnej. Głównym zabytkiem cytadeli jest centralnokopułowa świątynia o monumentalnych rozmiarach. Szczegółowy napis na południowej fasadzie informuje, że budowę zamku ukończono w 1689 r. na zlecenie najwyższego sędziego królewskiego Bardzima, brata Eristawi Aragwijskiego Giorgiego, wśród nazwisk występuje również Bagsaraszwili Kaichosro wymieniony jako osoba odpowiedzialna za budowę. Być może był on projektantem architektury świątyni. Świątynia Ananuri była najważniejszym budynkiem Gruzji w późniejszych wiekach. Wnętrze jest przestronne, dodatkowo Mistrz osiągnął niesamowity efekt, zwiększając szerokość ramion krzyża. Oświetlenie odgrywa tu dość istotna role, szczególnie godne uwagi jest aż 16 okien kopułowych. Taka liczba okien nie jest typowa dla gruzińskiej architektury kopułowej, spotykanej w Gelati (Čubinašvili, 1970, s. 3-320). Boczne przedziały ołtarza są dwupoziomowe. Schody umożliwiają dostęp do drugiego poziomu. Wloty wycięte są w ścianach w obszarze naw bocznych. Wewnętrzne ściany były pierwotnie pokryte malowidłami freskowymi, niestety większość fresków uległa zniszczeniu w trakcie pożaru podczas najazdu Lezginów w 1739 roku. Do dziś zachowały się jedynie małe fragmenty malowideł. Ogrodzenie znajduje się blisko świątyni ze wszystkich stron, dlatego nie można jej objąć jednym spojrzeniem z dziedzińca. Całą katedrę można zobaczyć tylko z daleka, z okolicznych wzgórz, ponieważ stoi na skraju wysokiej góry. Elewacje klasztoru zdobią bryły ociosanego kamienia. Autor Ananuri naśladuje odległych przodków nie tylko w łukowatym stylu fasad, ale także w wielu innych aspektach. W szczególności przywrócił centralną oś na wschodniej elewacji, którą wprowadził twórca Samtawisi. To prawda, że brakuje mu przydatności tkwiącej w starożytnych poprzednikach, jednakże stanowi wyznacznik jego epoki.

W XVI-XVIII wieku rozpowszechniły się dwa typy kościołów. Pierwszy, a zarazem główny typ to centralnokopułowy, drugim jest styl pałacowy. W tym okresie powrócił temat ,wolnego krzyża”, zachowane przykłady znajdują się w zachodniej Gruzji, są to: Tkwiri (Samegrelo); Koreisubani (Guria); Gulbandiani w Sakara i Giorgiseuli w Sawane (obie w Imereti). Można przytoczyć inne dzieła tego typu, jednak powyższe wystarczą aby stwierdzić, iż nurt ten nie był perspektywiczny i ciężko było stworzyć coś nowego $\mathrm{i}$ interesującego w tym kierunku. Wszystkie zabytki należą do okresu przejściowego: „Ormocta” („Czterdziestu Męczenników”) oraz „Dżwaris Mama” w Tbilisi („Ojciec Krzyża”) z XVI wieku.

Kościół Czterdziestu Męczenników w Kodżori stoi na wschód od wioski Kodżori, w gęstym lesie niedaleko twierdzy Koroglu, jego przykładna konstrukcja zbudowana została z cegły. Początkowo budynek mieścił się na planie jednego prostokąta, później zaś pojawily się przedhużenia od strony południowej. Kopuła spoczywa na rogach ołtarza i występach bocznych ścian na zachodzie. Ołtarz składa się z absydy i prostokątnych pomieszczeń bocznych. Drzwi znajdują się na południu i zachodzie, a okna wycięte zostały z każdej strony w celu doświetlenia wnętrza, z czego osiem okien znajduje się w kopule. Wewnątrz wszystkie łuki wraz z kopułą uformowane zostały w kształt strzały. $Z$ zewnątrz kościół charakteryzują równe proporcje, a jego elementy wyłożone zostały regularnymi rzędami cegieł. Do łuków użyto specjalnie wypalonej cegły (na drewnianej belce południowych drzwi kościoła zachował się uszkodzony napis ,asomtawruli”).

Pomimo indywidualnego charakteru architektury występującej jedynie w omawianym regionie cerkiew gruzińska podporządkowuje się w pełni tym zasadom, które zostały przyjęte w szerokim świecie wśród wyznawców chrześcijaństwa. Podstawowe cechy cerkwi gruzińskiej to półokrągłe apsydy, ołtarz skierowany w stronę wschodnią, diakonnik, ołtarz po obydwóch stronach.

$\mathrm{W}$ pracy podane opisy są oraz plany konkretnych budynków sakralnych należących do okresów zgodnie ze wspomnianym wyżej podziałem chronologicznym.

\section{Bibliografia}

Abramišvili, G., Zaharaâ, P. i Cicišvili, P. (1944). Istoriâ gruzinskoj arhitektury. 5-205 [Абрамишвили, Г., Захарая, П. и Цицишвили, П. (1944). История грузинской архитектуpbl. 5-205].

Agababân, R. (1950). Kompoziciâ kupol'nyh sooruženii Gruzii i Armenii. (s. 9-116). Erevan: Armgosizdat [Агабабян, Р.
(1950). Композиция купольных сооружении Грузии и Армении. (s. 9-116). Ереван: Армгосиздат].

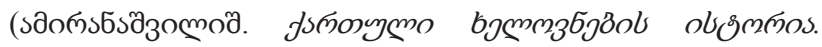

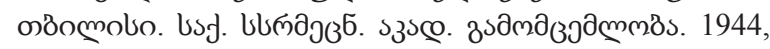
s.1-201,) Amiranašvili, Š. (1944). Istoriâ gruzinskogo iskusstva. (s. 1-201) Akademiâ Nauk Gruzii [Амиранашви- 
ли, Ш. (1944). История грузинского искусства. (с. 1-201) Академия Наук Грузии].

Beridze, V. (1976). Nekotorye aspekty Gruzinskoj kupol'noj arhitekturi so vtoroj poloviny Xv do konca XIII v. (c. 5-49) Tbilisi: Mecniereba [Беридзе, В. (1976). Некоторые аспекты Грузинской купольной архитектури со второй половины $X$ в. до конца XIII в. (с. 5-49) Тбилиси: Мецниереба].

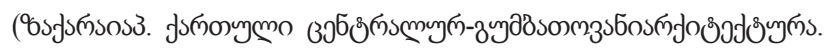

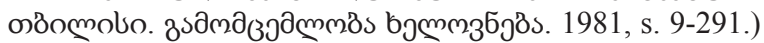
Zakaraia, P. (1981). Gruzinskaâ central'no-kupol'naâ arhitektura. (t.3). Tbilisi: Helovneba [Закараиа, П. (1981). Грузинская центрально-купольная архитектура. (т.3). Тбилиси: Хеловнеба].

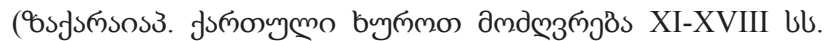

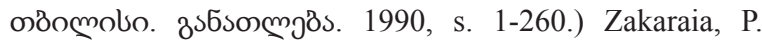
(1990). Gruzinskâ̂ arhitektura XI-XVIII vv. (t.1). Tbilisi: Ganatleba [Закараиа, П. (1990). Грузинская архитектура XI-XVIII вв. (т. 1). Тбилиси: Ганатлеба].

Zakaraia, P. (1992). Zodčestvo Tao-Klardžeti. (s. 5-189).Tbilisi:
Tbiliskij Universitet [Закараиа, П. (1992). Зодчество Taо-Кларджети. (s. 5-189). Тбилиси: Тбилиский Университет].

Severov, N.P., Čubinašvili, G.N. (1947). Kumurdo i Nikorcminda. Moskva [Северов, Н.П., Чубинашвили, Г.Н. (1947). Kyмурдо и Никориминда. Москва.].

Severov, N.P. (1947). Pamâtniki gruzinskogo zodčestva. Moskva [Северов, Н.П. (1947). Памятники грузинского зодчества. Москва.].

Čubinašvili, G. N. (1936). Istoriâ gruzinskogo iskusstva. 1. Tbilisi [Чубинашвили, Г. Н. (1936). История грузинского искусства. І. Тбилиси]

Čubinašvili, G. (1970). Voprosy istorii iskustva. (t.1, c. 3-320) Tbilisi: Helovneba [Чубинашвили, Г. (1970). Bопросы истории искуства. (т. 1, с. 3-320) Тбилиси: Хеловнеба].

Čubinašvili, G. (1948). Pamâtniki tipa Džvari. 3-197.Tbilisi: Izdatel'stvo Akademii Nauk Gruzinskoj SSR [Чубинашвили, Г. (1948). Памятники типа Джвари. 3-197. Тбилиси: Издательство Академии Наук Грузинской ССР].

Rozmiar artykułu: 1,6 arkusza wydawniczego 
ISSN 1508-7719

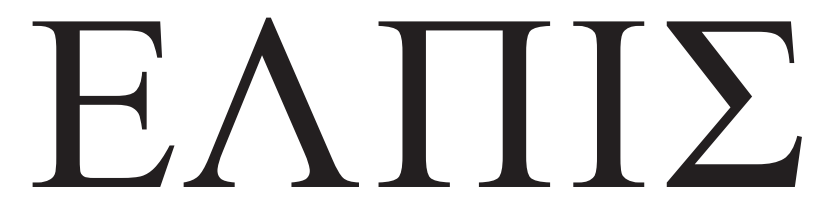

CZASOPISMO TEOLOGICZNE KATEDRY TEOLOGII PRAWOSŁAWNEJ UNIWERSYTETU W BIAŁYMSTOKU

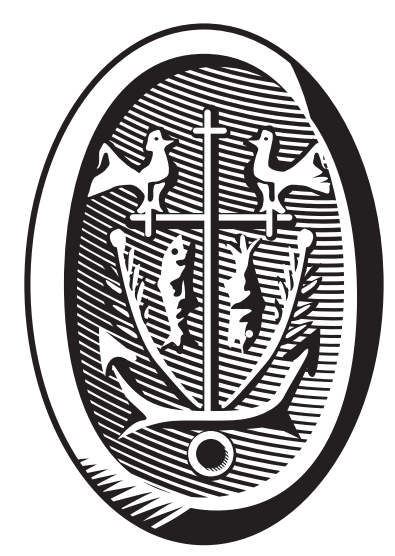

ADRES REDAKCJI

ul. Ludwika Zamenhofa 15, 15-435 Białystok, Polska tel. 85 745-77-80, e-mail: elpis@uwb.edu.pl www.elpis.uwb.edu.pl 